\title{
非構造三角形格子に基づく津波数値解析の GPGPUによる高速化 ON THE EFFICIENCY OF GPGPU ACCELERATION OF TSUNAMI SIMULATIONS USING AN UNSTRUCTURED TRIANGULAR MESH SYSTEM
}

\author{
曾新翔 1 ・赤穗良輔 2 ・石川忠晴 3 ・中村恭志 4 \\ Xinxiang ZENG, Ryosuke AKOH, Tadaharu ISHIKAWA and Takashi NAKAMURA \\ 1学生会員 工修 東京工業大学大学院博士課程 総合理工学研究科（†226-8502横浜市緑区長津田町4259番） \\ 2正会員 工博 東京工業大学大学院助教 総合理工学研究科（干226-8502横浜市緑区長津田町4259番） \\ 3 フェロー 工博 東京工業大学大学院教授 総合理工学研究科（†226-8502横浜市緑区長津田町4259番） \\ 4正会員 理博 東京工業大学大学院准教授 総合理工学研究科（干226-8502横浜市緑区長津田町4259番)
}

In consequence of the huge spatial scale, the computation load of Tsunami simulation tends to be too large to afford. In order to overcome this difficulty, a rapid numerical simulator was constructed by applying the GPGPU technology to solve the 2-dimensional shallow water equations. This simulator is based on an explicit finite volume scheme combined with unstructured triangular meshes. With the power of GPGPU, this simulator can be used to simulate large scale Tsunami movement. Furthermore, by using unstructured meshes, complex boundary could also be represented well. And, the Recursive Spectral Bisection (RSB) method was used to enable GPU computations. The simulation results for the run-up Tsunami in Tone River caused by Tohoku earthquake (2011) are verified and validated, and show that it is sufficiently accurate for real-world simulations.

Key Words : GPGPU, Shallow water equations, Unstructured mesh, Finite volume method, Recursive Spectral Bisection (RSB), Tohoku Earthquake (2011)

\section{1. 序論}

平成23年東北地方太平洋沖地震(以下，東北地震)では 観測史上最大級の津波により甚大な被害が生じた。津波 の数值解析では，外洋を含む広大な領域を，局所的な地 形変動に合わせた細かい計算メッシュで解く必要がある ため，多大な計算負荷と時間が必要とされる．東北地震 では河川を遡上した津波により浸水被害地域が拡大した。 今後の河川遡上まで含めた解析ではより細かいメッシュ の採用が予想され，増大寸る計算負荷の問題を解決する ことが求められている．実際，筆者らが近年開発を進め ている非構造格子による津波解析モデルを利根川下流域 での津波遡上計算に適用した際には，計算負荷低減のた めに河川と海洋を個別に解く工夫(ネスティング)を必要 とし，高計算負荷の問題は解決できていなかった1).

一方，General-Purpose Computing on Graphics Processing Units (GPGPU)による高速並列計算が近年注目され，津 波解析への適用も試みられつつある2).GPGPUにより効 率的な並列計算を実現するには，計算負荷の均一化，サ ブドメイン外部から参照する格子点数の最小化などの要
請を満たした領域分割が必要となる．三角形格子からな る非構造格子は地形形状の表現に優れる一方, 格子の大 きさや配置が不規則となるため，上記要請を完全に満足 する領域分割は出来ないのが普通である。その一方，非 構造格子へGPGPUを適用した例は数少なく3),4)，非構造 格子における領域分割の不完全性がGPGPUによる津波 解析の高速化に与える影響について詳細な報告をした研 究は見られない，そこで本研究では，筆者らの非構造三 角形格子を用いた有限体積モデルにGPGPUを適用した 津波数值解析モデルを新たに開発し，利根川下流域での 津波遡上の再現計算により GPGPUの有効性を検証する とともに，非構造格子における不完全な領域分割が高速 化へ与える影響について調査することとした.

\section{2. 計算モデル}

\section{（1）基礎方程式}

以下の二次元浅水方程式を基礎方程式とした.

$\frac{\partial}{\partial t} \mathbf{q}+\frac{\partial}{\partial x} \mathbf{F}+\frac{\partial}{\partial y} \mathbf{G}=\mathbf{S}_{b}+\mathbf{S}$ 


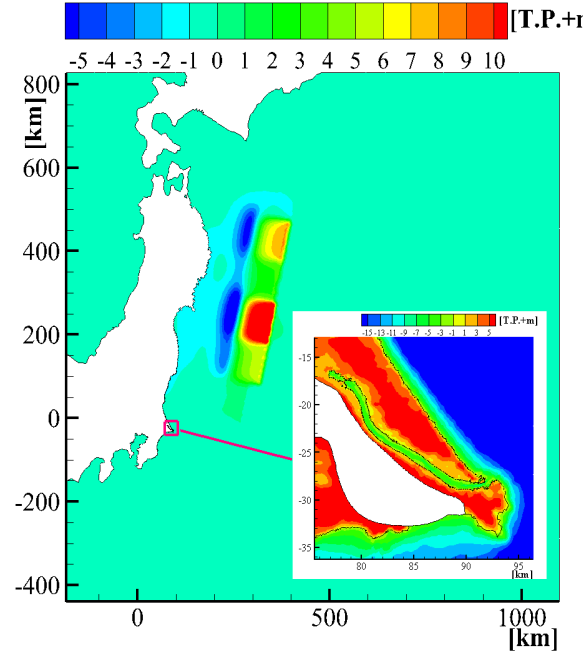

図-1 計算領域. カラーコンターは検証計算の初期水位分布 を表す. 右下には利根川付近の地形を拡大して示す.

表-1 検証計算に使用したメッシュ

\begin{tabular}{llrrrr}
\multicolumn{5}{c}{} & \multicolumn{2}{c}{ メッシュ:(1) } & \multicolumn{1}{c}{ (2) } & \multicolumn{1}{c}{ (3) } & \multicolumn{1}{c}{ (4) } \\
\hline \multicolumn{2}{l}{ 総メッシュ数 } & 34,060 & 139,119 & 266,194 & 452,901 \\
\hline メッシュ & 海洋 & $7.5 \mathrm{~km}$ & $4.0 \mathrm{~km}$ & $7.5 \mathrm{~km}$ & $4.0 \mathrm{~km}$ \\
\cline { 2 - 7 } サイズ & 利根川 & $150 \mathrm{~m}$ & $30 \mathrm{~m}$ & $25 \mathrm{~m}$ & $15 \mathrm{~m}$ \\
\hline メモリー量[MB] & 5 & 24 & 46 & 79 \\
\hline
\end{tabular}

$\mathbf{q}=\left[\begin{array}{l}h \\ h u \\ h v\end{array}\right], \mathbf{F}=\left[\begin{array}{l}h u \\ h u^{2}+g h^{2} / 2 \\ h u v\end{array}\right], \mathbf{G}=\left[\begin{array}{l}h v \\ h u v \\ h v^{2}+g h^{2} / 2\end{array}\right]$

ここでhは水深， $h u$ と $h v$ はそれぞれ $x$ と $y$ 方向の線流量で ある. $\mathrm{g}$ は重力加速度であり， $\mathrm{S}_{b}$ は水底勾配の効果を表 し，Sはレイノルズ応力と底面摩擦などを含むソース項 である，底面摩擦はマニング則から決定し，レイノルズ 応力は0方程式モデルに基づく水深平均值を使用した. 詳細な定式化については文献をを参照されたい.

\section{（2）非構造三角形格子}

計算領域を図-1に示寸。三角形非構造格子を用いて離 散化を行う．表-1に示すように空間解像度の異なる 4 種 類の格子(メッシュ(1)〜 (4))を用いる. 図-2には最も粗い (1)と最も細かい(4)を示す. (1)～(4)の全ての格子で海洋か ら沿岸に近づくにつれ細かい格子となるよう調整してい る. (a-2) 及び (b-2)には利根川部分を拡大して示してい る. 最も粗い(1)の場合には横断方向に十メッシュ以下で 離散化されるため河岸線がいびつになっている．一方(4) では利根川部は15m程度の細かいメッシュが使用され， 河岸線等地形が詳細に表現されている.

\section{(3) 計算手法}

赤穗らと同様に有限体積法を使用した ${ }^{1)}$ 。図-3に概念 図を示す．変数 $\mathbf{q}=(h, u, v)$ はメッシュ重心に配置され，境 界面での数值流束を基に次式により計算される.
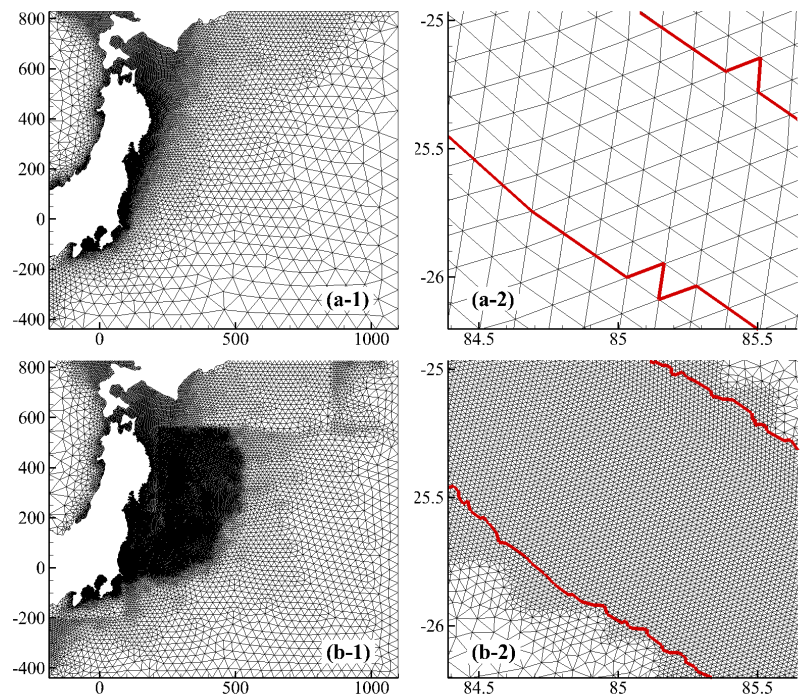

図-2 計算メッシュ（a-1) と (b-1) はメッシュ(1)及び(4)の 全体を示し, (a-2) 及び (b-2) は利根川の一部の拡大であり， 赤線が河岸線である.

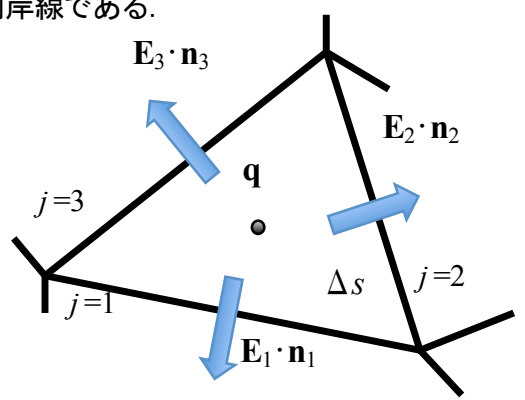

図-3 三角形格子における数值流束と変数配置.

$$
\mathbf{q}^{n+1}=\mathbf{q}^{n}-\frac{\Delta t}{\Delta s}\left(\sum_{j=1}^{3}\left(\mathbf{E}_{j} \cdot \mathbf{n}_{j} d l_{j}\right)-\Delta s \mathbf{S}_{b}\right)+\Delta t \mathbf{S}
$$

ここで $\Delta \mathrm{s}$ は面積, $\mathbf{n}_{j}, d l_{j}$ は辺 $j$ 上の単位法線ベクトル及び 辺長である. $\mathbf{E}=(\mathbf{F}, \mathbf{G})$ は辺 $j$ を通過寸る数值流束テンソ ルであり，近似Riemann解法であるRoe法を用いて陽的 に評価する1),5).

\section{GPGPUに基づくプログラム実装}

\section{（1）GPGPUによる高速計算の原理}

GPUは拡張カードとしてPCに組込まれる，PC上の CPUとは内部バス(PCI Express)を通じてデータ転送を行 う。本研究ではGPGPU用に開発されたTesla C1060 (Nvidia社)を使用したが，通常の画像描画用GPUでも GPGPUとして使用可能である. 図-4にNvidia社GPUの内 部構成の模式図を示寸. 図-4 (a) に示すように, GPU上 には数GBのGlobalメモリーがあり, 変数qなどのデータ は全てここに保存されて時間発展が計算される．演算を 受け持つ複数のMulti-Processor(MP)が二個一組でGPU上 に配置される. CPU上の演算coreに相当し，実際の数值 演算を担当するStreaming Processor(SP)が各MP上に8個ず つ配置される(図-4(b)). Tesla C1060は30個のMPを持ち, 総計240個のSPを並列害行することで計算の高速化を実 現する. 今回使用したTesla C1060は2008年末に発売され 


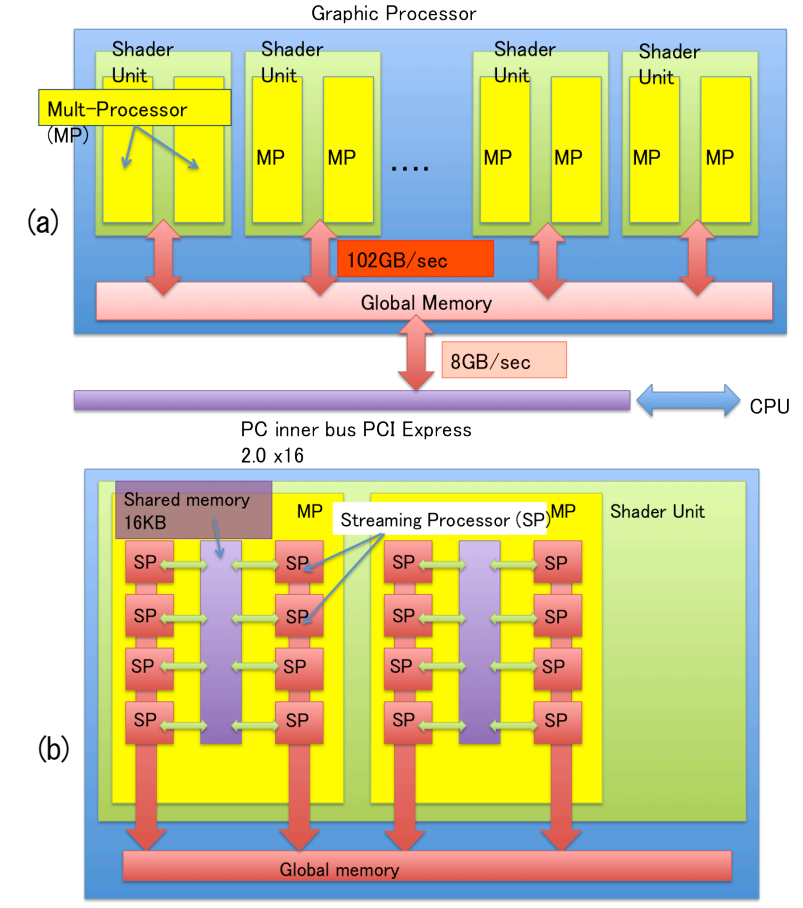

図-4 GPUの内部構造の模式図.

たもので，GPGPU専用のGPU としては第 1 世代に属す る比較的古い装置である. Tesla C1060の理論演算性能は, 単精度浮動小数型 (いわゆる float 型) 変数では 933GFLOPSに達する一方, 倍精度浮動小数型(いわゆる double型)変数では78GFLOPS と大幅に悪化する難点を 持っている. float型変数を用いることは演算誤差の増大 を引き起こす危険がある。しかしながら，今回の研究で はGPGPUの高速計算の潜在能力を示すため, あえて全 てfloat型変数を用いて計算を行うこととした。なお, 2012年11月にはNvidia社より最新世代のTesla K20が発表 されている.このGPUではdouble型変数の理論演算速度 が大幅に改善され，Tesla C1060のfloat型演算性能を超え る1.17TFLOPSに達するとされている，そのため, 最新 世代のTesla K20を使用すれば， double型変数を用いて計 算したとしても，今回報告する結果と同程度の高速化を 実現できる可能性がある. なお， Tesla C1060の価格は25 万円程度(2008年発売時)であり, コストパフォーマンス が非常に高い点もGPGPUの特徴である.

\section{（2）プログラム実装}

図-4(b)に示すように，各MP内には低容量だが非常に 高速なSharedメモリーが実装されており，同じMP内の SP間ではSharedメモリー上に保存された值を相互に参照 可能となっている。一方, 異なるMP上のSharedメモ リーの值は参照することは出来ない。この状況は, PC クラスター上で並列計算を行う場合の各"PC"が"MP"に 相当し，各"PC"上のメモリーが"MP"内のSharedメモリー に相当すると考えれば理解し易い6). 実際のプログラム では計算領域を幾つかの小領域(サブドメイン)に分割す る領域分割法のにより並列計算を実現する。図-5に実際 に分割された様子をサブドメインごとに色分けして示す.

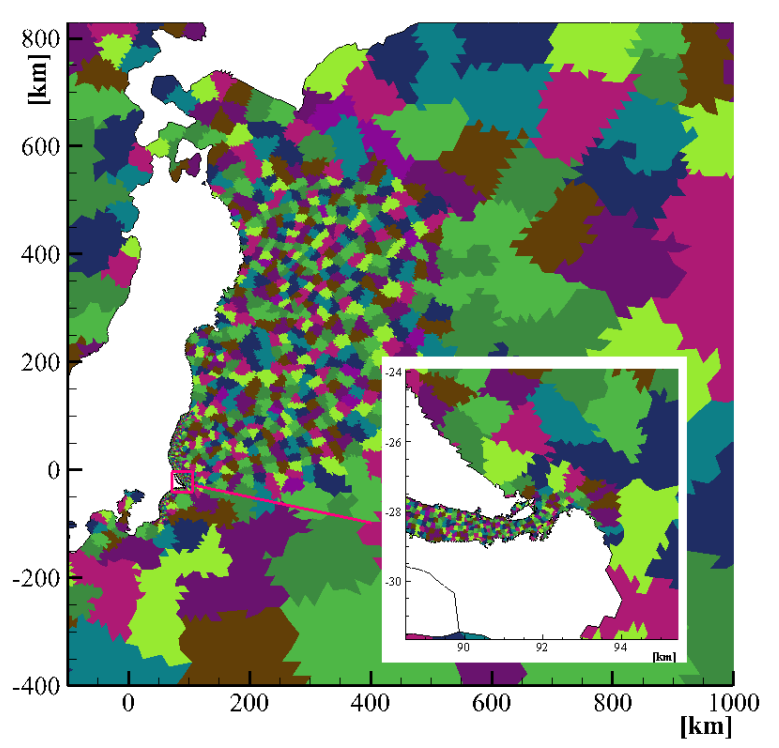

図-5 RSB法による領域分割の結果. サブドメインを色分け して示している.

(a)

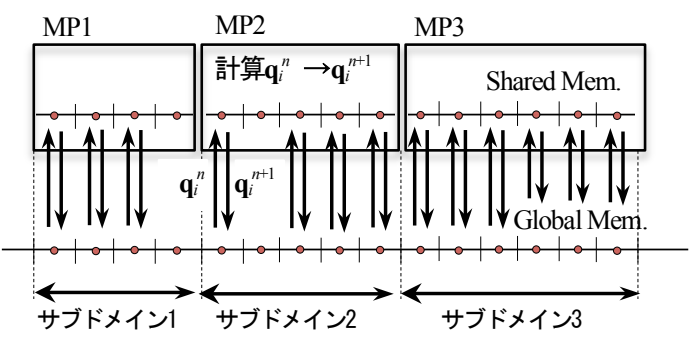

(b)

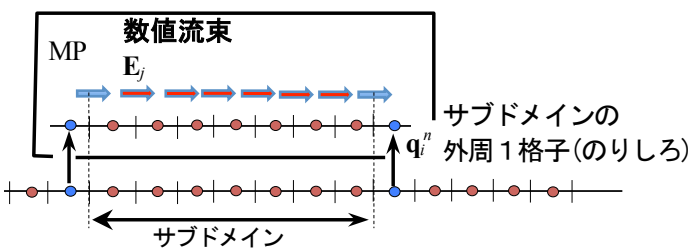

図-6ＧPGPUによる並列計算の概念図.

また，図-6に並列計算の概念図を示寸，実際の解析は二 次元空間で行われるが，図-6では説明のため一次元格子 で概念を示している. 図-6(a)に示すように，まず各サ ブドメインがMPに振分けられ，計算に必要な值 $\mathbf{q}^{n}$ が GlobalメモリーからMP内のSharedメモリーに読込まれる。 その後, MP内の複数のSP はSharedメモリー上の值を相 互に参照しながら次時刻の值 $\mathbf{q}^{n+1}$ を計算する. 最後に $\mathbf{q}^{n+1}$ が再度Globalメモリー上に書き込まれる。.今回のモ デルでは数值流束 $\mathbf{E}_{j}$ は陽的に前時刻の值 $\mathbf{q}^{n}$ のみを用いて 計算されるため，異なるMP上での計算結果 $\mathbf{q}^{n+1}$ を相互に 参照する必要は無い. そのため, 各MPの計算は他のMP とは独立となり，完全に並列で実行されることになる. その一方， $\mathbf{E}_{j}$ は境界面上で計算されることから，サブド メイン境界面での $\mathbf{E}_{j}$ (図-6 (b) 青矢印) を計算するために サブドメイン外に隣接する 1 格子 (図-6 (b) 青丸) の值 $\mathbf{q}^{n}$ も余分に"のりしろ"としてMP内へ読込む必要が生じる. 二次元空間における実際の"のりしろ"の格子点数は, サ ブドメインの境界線をどのように引くかで決まる.

以上のように並列計算は各MPを単位として行われる. そのため, 効率的な計算の高速化には, 計算負荷を各 


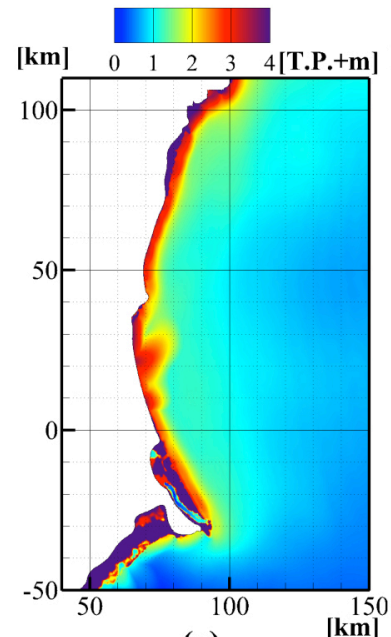

(a)

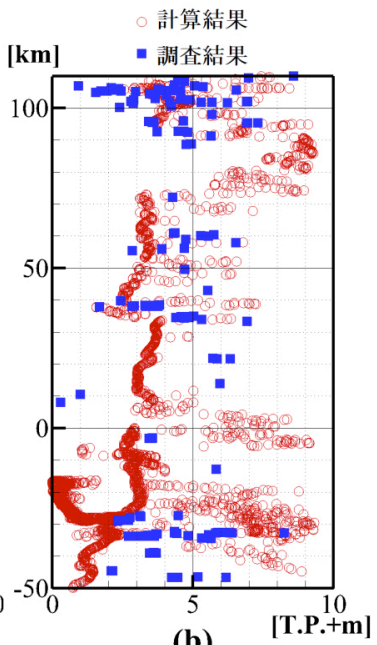

(b)
$[$ T.P. + +m]
図-7 茨城県沿岸における (a) 最大波高分布の計算結果, 及び (b) 観測值との比較.

MPに均等に配分するためサブドメインに含まれる格子 数は同程度に調整すること, 或は"のりしろ"の格子数を 出来るだけ少なくするようサブドメインを分割すること が要請される. 本研究では非構造格子の領域分割法とし て，グラフ理論に基づくRecursive Spectral Bisection(RSB) 法7),8)を使用することとしたが, 非構造格子の効率的な領 域分割法は現在も模索されている段階にあり，格子の不 均一性のため非構造格子で上記要請を完全に満足した領 域分割を得ることは依然難しい状況にある．実際のプロ グラム実装ではGPUへのデータ転送や同期処理などの考 慮が必要であり，GPGPUの為のコードを別途書く必要 がある．本研究ではGPUメーカーであるNvidia社が開発 したCUDAライブラリ早を使用した。

\section{4. 東北地震津波の再現計算と計算高速化の検討}

\section{(1) 計算条件}

計算開始は2011年3月11日14:52とし，17:52までの3時

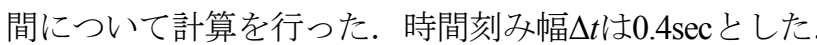
津波の初期波形は東北大学モデル(Version 1.0)を基に設 定した ${ }^{10)}$. 利根川河道内部は14:00〜 15:00の観測水位か ら時間方向に補間して，-0.49 T.P.mとした。初期水位分 布は図-1に示されている。 また水深が $0.1 \mathrm{~m}$ 超えた場合 に水没するとして，水際線の移動を考慮している．水底 摩擦に用いるマニング係数は土地利用形態を元に，低水 路・海洋部を 0.02 , 高水敷・陸地を 0.04 と設定した.

\section{（2）観測結果との比較}

以下，特にことわりの無い場合，最も細かいメッシュ (4)を使用した結果を示す。図一7には茨城沿岸における最 高水位分布と痕跡調査などによる推定值との比較を示す. 推定水位にはばらつきが観られるが，図-7 (b) に示すよ うに計算結果は最大水位と概小一致している。図-8には 利根川において津波の水位データが観測された地点を黒 丸で示す。"KP"は河口からの距離である。18.5KPには利

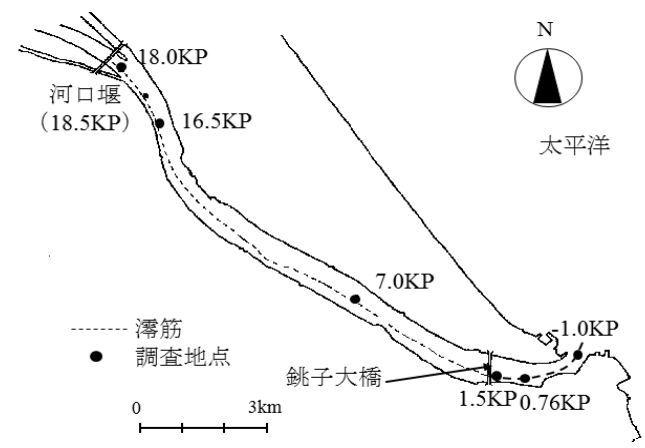

図-8＼cjkstart利根川下流域における水位観測点位置.

根川河口堰がある。図-9に利根川付近を拡大して水位時 間変化を示す．地震発生40分後には河口に第一波が到達 （t1）し，上流に向け遡上していく(t2). 大凡100分後に は河口堰に到達した第一波は堰で反射される一方，後続 の第二波が河口から遡上開始している(t3). その後 14KP付近では反射波と第二波が重なり，水位が局所的 に増大している (t5)。図-10には各観測点における水位 時間変化の比較を示す. メッシュ(4)の結果を赤実線で示 したが，第一波及び後続波の来襲時刻とその波高は観測 結果と良く一致しており，河道部で $15 \mathrm{~m}$ 程度の非常に細 かいメッシュを使用することで，河川内を遡上する津波 を良く再現できている，一方，図-10には最も粗いメッ シュ (1)を使用した場合の結果も青実線で示しているが, 数值拡散誤差に起因すると思われる波高の減衰が見受け られる。このことから，津波の河川遡上を評価する為に は河道スケールに合わせた細かいメッシュの使用が必要 であることが確認できる。また図-10 (a) と (b)の両方で， 上流の $16.5 \mathrm{KP}$ と $18.0 \mathrm{KP}$ における計算水位は観測結果より 過小に計算されている(特に経過時間140分頃)ことが確認 できる．この差異は細かいメッシュ(4)を用いた場合にも 見られることから，使用するメッシュの粗細以外の何ら かの原因が示唆される. 原因の候補として, パラメータ のキャリブレーション不足がある．例えば，河床摩擦に おけるマニング係数は河川の標準的な值(低水路 0.02 ，高 水敷0.04)を使用したが，これらの值が過大であったため 上流に達するまでに津波が大きく減衰した可能性がある. これらパラメータは観測值などを用いて調整することが 可能であり，今後の検討が必要である.

\section{（3）GPGPUによる計算高速化の検証}

メッシュ (1)〜 (4)夫々について，3時間の再現計算に必 要とした実行時間を調べた。また比較の為, 通常の GPGPUを用いないCPU (Core i7 920, 2.67GHz)による計算 も行い，実行時間を比較した。結果を表-2に示す。一般 に計算そのものに比べて途中結果などをファイルに書き 出す操作は遅いことが知られている。そこで，途中結果 の出力を行わない場合と行う場合のそれぞれについて実 行時間を計測した．表-2には出力を行わない場合を括弧 なしで示し, 出力した場合(水位, 流速を1分毎に出力)を 括弧付きの数值で示した. 


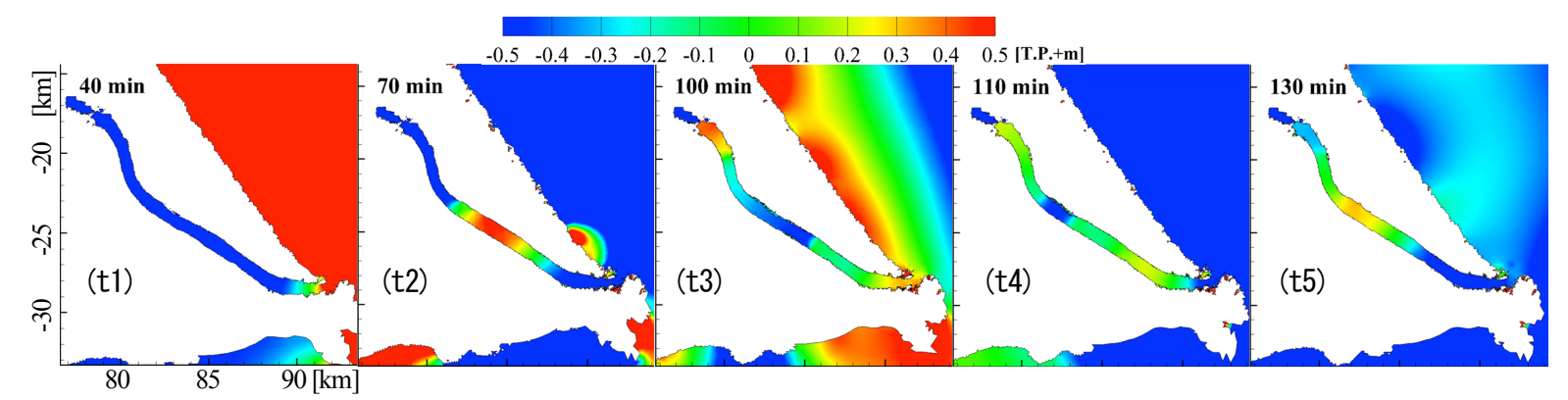

図-9＼cjkstart利根川下流域における水位計算結果.
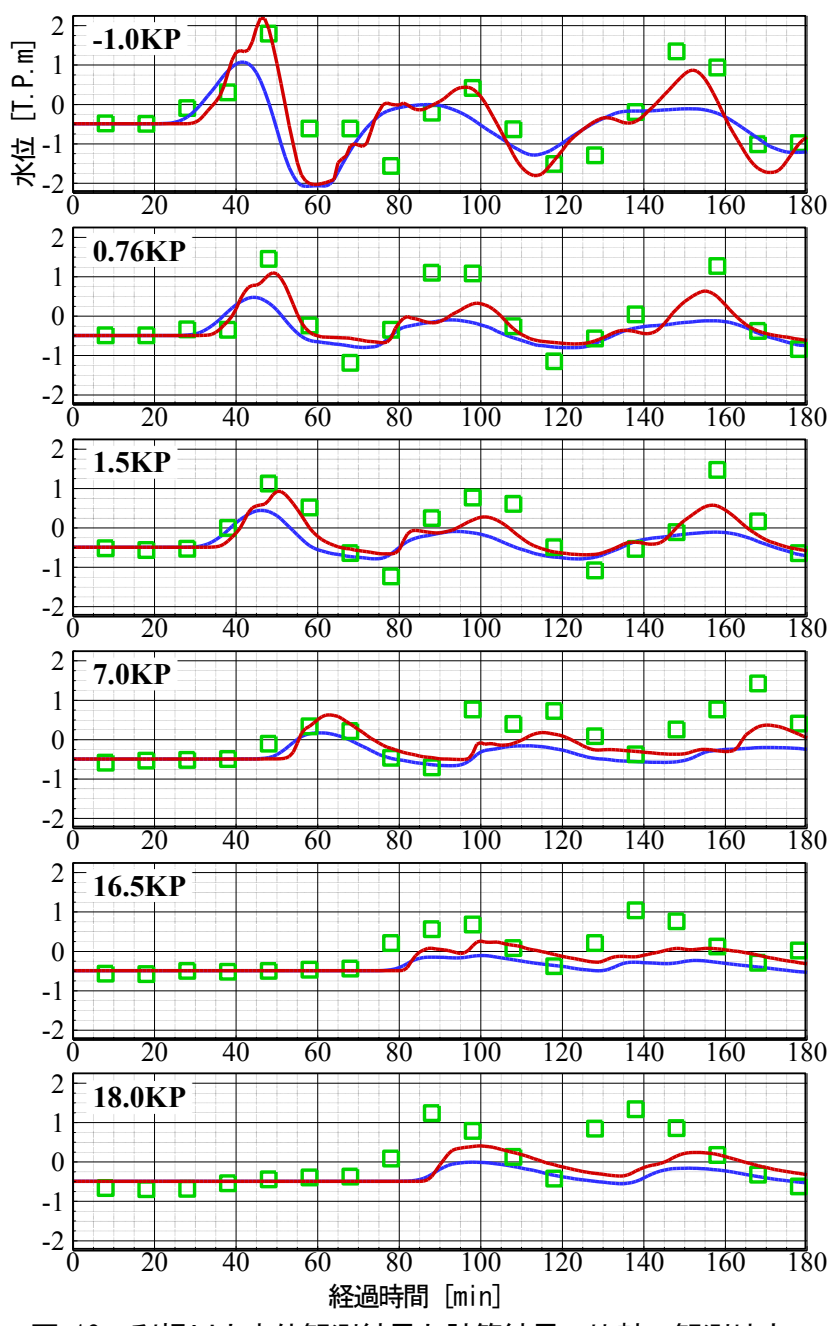

図-10 利根川内水位観測結果と計算結果の比較. 観測地点 ごとの時間変化について，緑四角で観測結果，赤実線でメッ シュ(4)の計算結果, 青実線でメッシュ(1)の計算結果を示す.

まず途中結果の出力を行わない純粋な計算のみで比較 すると，どのメッシュ数でも概ね250倍程度計算が高速化 されている. 最も細かい(4)でも，GPGPUは3時間の解析 を僅か20分で完了している，一方，CPUのみの場合には (4)で16時間，最も粗い(1)でも1時間強が必要となる．東 北地震では津波第一波は30分後には沿岸に到達している. 30分の計算に必要な時間に換算すれば，最も細かい(4)で GPGPU:3分強, CPU:5時間強であり, 詳細なメッシュを 使用してもGPGPUによりリアルタイム予報が実現でき る可能性がある。一方，途中結果の出力を行った場合に は, 計算の高速化率は25倍程度に減少している. 出力と それ以外の計算に要した時間の内訳を表-3に示す。ファ
イルへの出力は並列化することは不可能であり高速化す ることは出来ない. そのため, 出力が全体の実行時間に 占める割合がGPGPUでは相対的に大きくなり，計算そ のものと同程度の時間を出力に費やす結果となっている。 またGPGPUで出力を行う場合には，ファイルへの書込 みに加え, GPU上のデータを低速な内部バスを通じて取 得する必要がある。そのため出力に関する時間が GPGPUでは増加すると予想されたが，CPUのみの場合 之同程度の時間で出力を終えており, 今回の計算では有 意な遅延は見られない。これは表-1に示寸ように，使用 メモリー量が小さかった(最大でも80MB)ため, GPUか らのデータ転送に費や寸時間がファイル出力に比べ無視 できるほど小さかったためと考えられる. 以上の様に, GPGPUでは出力やデータ転送などの処理が全体の計算 速度を律する可能性があり, 途中結果の出力間隔を適切 に取るなどの考慮が重要となることが示唆される.

次に領域分割が計算速度に与える影響について検討寸 る. 以下では, 途中結果の出力を行わないとしている. まず，サブドメイン内に含まれるメッシュ数(サブメッ シュ数)を変化させ，その実行時間への影響を調べた結 果を図-11に示す. サブメッシュ数はサブドメイン毎に ばらつくが，サブメッシュ数の平均值を横軸に示してい る.メッシュ(1)〜(4)について各々色を変えて示している. 平均サブメッシュ数が増加するに従い実行時間が減少し, 効率的に計算が高速化されていくことが確認できる. 平 均サブメッシュ数が 20 メッュュ程度と200程度の場合を 比較すると，(1)～(4)何れのメッシュでも4倍程度も計算 速度が異なる．これには幾つかの原因が考えられる。

非構造格子の領域分割ではサブメッシュ数にはバラッ キが生じやすい，多いサブメッシュ数のサブドメインは 他よりも計算に長い時間を必要とするため, サブメッ シュ数の不均一は全体の計算効率を悪化させる可能性が ある. バラツキの指標としてサブメッシュ数の標準偏差 を考える. 図-12には平均サブメッシュ数に対する標準 偏差の変化を実線で示した，平均サブメッシュ数が大き い，即ち大きいサブドメインで分割する場合ほどサブ メッシュ数の標準偏差(バラツキ)が大きくなっている. ひとつのMP上で実行される計算の大凡の総量は平均サ ブメッシュ数に, MP間の計算量の差異はバラツキ(標準 偏差)に比例すると考えられる，そこで，平均サブメッ シュ数に対する標準偏差の割合を見てみると，図-12破 線で示す様に大きなサブドメイン(サブメッシュ数)を用 
表-2 実行時間の比較. 括弧内の数字は途中結果を 1 分毎に出力した場合.

\begin{tabular}{|c|c|c|c|c|c|c|c|c|c|}
\hline \multirow{2}{*}{\multicolumn{2}{|c|}{ 使用サブドメイン数 }} & \multicolumn{2}{|c|}{ メッシュ:(1) } & \multicolumn{2}{|c|}{ (2) } & \multicolumn{2}{|c|}{ (3) } & \multicolumn{2}{|c|}{ (4) } \\
\hline & & \multicolumn{2}{|c|}{256} & \multicolumn{2}{|c|}{1,024} & \multicolumn{2}{|c|}{2,048} & \multicolumn{2}{|c|}{4,096} \\
\hline \multirow{2}{*}{$\begin{array}{l}\text { 実行時間 } \\
\text { [min] }\end{array}$} & GPGPU を使用 $(A)$ & 1.3 & $(2.5)$ & 5.2 & $(9.7)$ & 10.9 & $(20.0)$ & 21.4 & $(37.1)$ \\
\hline & CPU のみ (B) & 71.2 & (72. 3) & 246.7 & $(251.6)$ & 535.4 & $(544.6)$ & 964.2 & $(979.8)$ \\
\hline \multicolumn{2}{|c|}{ 計算高速化率 $[=(\mathrm{B}) /(\mathrm{A})]$} & 54.8 & $(28.9)$ & 47.4 & $(25.9)$ & 49.1 & $(27.2)$ & 45.1 & $(26.4)$ \\
\hline
\end{tabular}

\begin{tabular}{|c|c|c|c|c|c|c|c|c|c|}
\hline & & \multicolumn{4}{|c|}{ 表-3 出力と計算に関する実行時間. } & \multicolumn{2}{|c|}{ (3) } & \multicolumn{2}{|c|}{ (4) } \\
\hline & & GPGPU & $\mathrm{CPU}$ & GPGPU & CPU & GPGPU & CPU & GPGPU & CPU \\
\hline \multirow[t]{2}{*}{ 実行時間[min] } & 計算 (A) & 1.3 & 71.2 & 5.2 & 246.7 & 10.9 & 535.4 & 21.4 & 964.2 \\
\hline & 出力 (B) & 1.2 & 1.1 & 4.5 & 4.9 & 9.1 & 9.2 & 15.7 & 15.6 \\
\hline \multicolumn{2}{|c|}{$\begin{array}{l}\text { 出力の総実行時間に占める割合 } \\
{[=(B) /(A+B)]}\end{array}$} & $48 \%$ & $1.5 \%$ & $46 \%$ & $1.9 \%$ & $46 \%$ & $1.7 \%$ & $42 \%$ & $1.6 \%$ \\
\hline
\end{tabular}

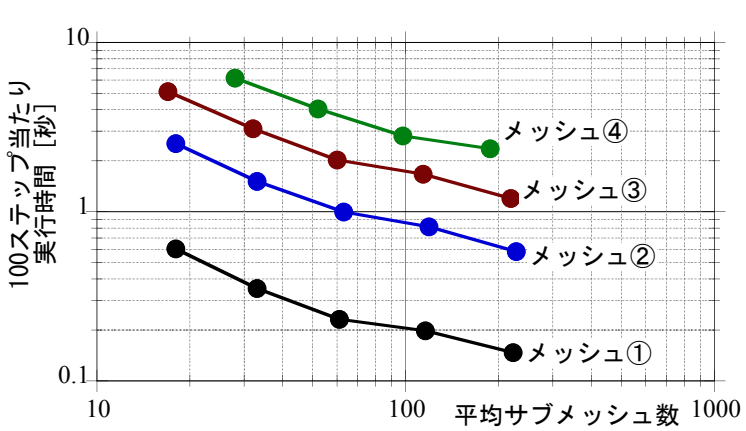

図-11 サブメッシュ数に対する計算速度の変化.

いた方が割合は小さくなる。これは大きなサブドメイン を用いた方が，サブメッシュ数のバラツキによる計算量 の不均一が総計算量に対して相対的に小さくなることを 意味している，その結果，図-11で示すように大きなサ ブドメインを用いた方が高速化されたものと考えられる。 また，数值流束をメッシュ辺上で計算するため，各サブ ドメイン縁部に隣接する 1 メッシュを余分に"のりしろ" としてMP上に読み込ませている。そのためサブメッ シュ数が減少するにつれ，サブメッシュ数に対するこの "のりしろ"の個数が相対的に大きくなり，計算速度が低 下したことも原因と考えられる. 以上のことから， GPGPUを用いた計算の高速化ではサブドメインを或る 程度大きく取ることが重要であることが示唆される.

\section{4. 結論}

非構造三角形格子に基づく津波数值解析へのGPGPU の有効性について検討を行った. GPGPUによる 2 次元 浅水方程式コードを開発し，東北地震の津波再現計算を 行った. 計算結果は観測水位と概ね一致し, 細かい計算 メッシュを用いた解析が津波の河川遡上等，局所的な地 形変動が重要となる現象に有効であることを示した。ま た，計算の高速化の程度は領域分割の影響を受けること を示し，比較的大きなサブドメインの方が計算は高速化 されることを確認した。通常のCPUのみを用いた解析と 実行時間を比較し，GPGPUを用いることで50倍程度の 高速化が実現可能であることを示した.

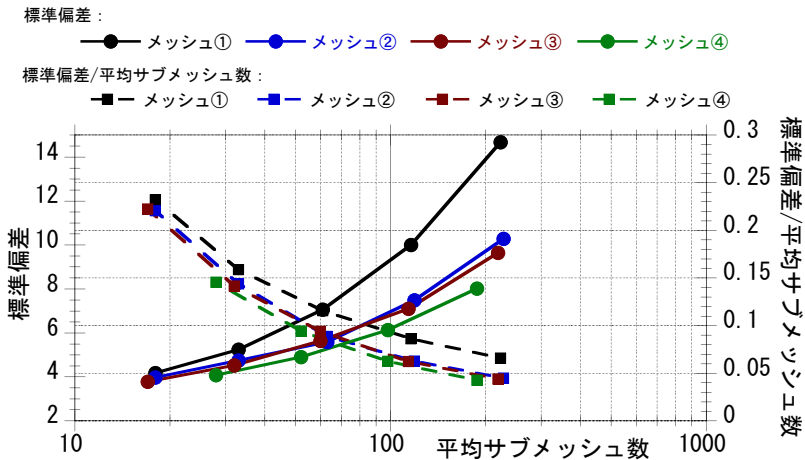

図-12 サブメッシュ数の標準偏差(実線) と標準偏差の平 均サブメッシュ数に対する割合 (破線).

\section{参考文献}

1) 赤穗良輔, 石川忠晴: 平成23年東北地方太平洋沖地震津波に おける利根川下流の津波遡上再現計算, 水工学論文集, $\mathbf{5 6}$, pp.I_1543-I_1548, 2012.

2) 青木尊之:双曲型方程式のGPUによる高速計算, 応用数理, 20 , pp.6-18, 2010.

3) Castro, M. J., Ortega, S., Asunción, M., Mantas, J. M., Gallardo, J. M.: GPU computing for shallow water flow simulation based on finite volume schemes, High Performance Computing, 339, pp.165184, 2011.

4) 曾新翔，赤穗良輔，中村恭志:非構造格子に基づく浅水波方 程式解法のGPGPUによる高速化, 第25回計算力学講演会, 神 戸, pp.273-275, 2012.

5) R. J. Leveque: Finite Volume Methods for Hyperbolic Problems, Cambridge University Press, 2002.

6)中村恭志, 川田重夫:MPIによる並列プログラミングと分散 PSEシステム, 物理探査学会誌, 57, pp.591-603, 2004.

7) H. D. SIMON: Partitioning of unstructured problems for parallel processing, Computing Systems in Engineering, 2, pp.135-148, 1991.

8) A. Pothen, H. Simon, and K.-P. Liou: Partitioning sparse matrices with eigenvectors of graphs, SIAM J. Mat. Anal. Appl., 11, pp.430452, 1991.

9) Nvidia: http://www.nvidia.com/object/cuda_home_new.html.

10) 今村文彦, 越村俊一, 大家隆行, 馬㴊幸雄, 村嶋陽一: 東 北地方太平洋沖地震を対象とした津波シミュレーションの実 施 東北大学モデル(version1.0), 東北大学大学院工学研究科 付属災害制御研究センター, 2011.

(2012. 9. 30受付) 